\title{
LUMBUNG PAPRIKA INDONESIA: DESA PASIRLANGU \\ Studi Kasus Komunikasi Pertanian di Desa Pasirlangu Kabupaten Bandung Barat sebagai Lumbung Pertanian Paprika di Indonesia
}

\author{
Jenny Ratna Suminar, Cut Meutia Karolina, dan Eny Ratnasari \\ Universitas Padjadjaran \\ Jalan Raya Bandung-Sumedang Km 21, Jatinangor, Kabupaten Sumedang, Jawa Barat, 45363 \\ jenny.suminar@unpad.ac.id, cut12001@mail.unpad.ac.id, eny12001@mail.unpad.ac.id
}

\begin{abstract}
ABSTRAK
Desa Pasirlangu dikenal sebagai daerah penghasil paprika. Ada kekhawatiran dari beberapa pihak atas keberlanjutan Desa Pasirlangu sebagai lumbung paprika dikarenakan kecenderungan generasi penerus yang kurang antusias untuk melanjutkan kiprah para pendahulunya. Penelitian ini bertujuan untuk memotret dan memahami pola komunikasi pertanian masyarakat. Metode penelitian yang digunakan adalah kualitatif dengan tradisi studi kasus, sehingga data diambil dengan teknik wawancara mendalam dan observasi dari beberapa narasumber. Hasil penelitian diperoleh bahwa ada dua pola komunikasi yang terjadi yaitu pola komunikasi petani individu dan petani kelompok. Pola komunikasi petani individu dikategorikan sebagai pola komunikasi primer dan sekunder. Karena petani individu satu dengan yang lain berkomunikasi secara langsung dan menggunakan media elektronik handphone melalui aplikasi pesan. Sedangkan, pola komunikasi petani kelompok dikategorikan sebagai pola komunikasi primer, sekunder, dan sirkular. Karena dalam proses mencari dan membagi informasi pada petani yang lain khususnya kelompok yang menjadi opinion leader adalah ketua kelompok. Selain itu, karena para kelompok tani juga berkomunikasi secara langsung dan bermedia elektronik berupa handphone melalui aplikasi.
\end{abstract}

Kata Kunci: Komunikasi Pertanian, Paprika, Desa Pasirlangu 


\section{PENDAHULUAN}

Jawa Barat memiliki sektor ekonomi yang dominan yaitu industri dan pertanian. Sektor pertanian utama yang menjadi andalan Provinsi Jawa Barat adalah sayur dan buah, hal ini didukung oleh kondisi geografi dan iklim yang cukup sesuai dan ramah pertanian. Salah satu komoditi pertanian Jawa Barat yang memiliki prospek cerah baik pasar luar dan dalam negeri adalah paprika. Paprika atau cabai manis merupakan tanaman hortikultura asal Amerika Selatan yang telah lama dibudidayakan di Indonesia. Kebutuhan dunia akan komoditas paprika diprediksi akan terus meningkat seiring dengan meningkatnya populasi, hotel, restoran, katering, dan pasar swalayan di kota-kota besar.

Berdasarkan data dari Badan Pusat Statistik (BPS) dan Direktorat Jenderal Hortikultura, produksi sayuran di Indonesia tahun 2014-2017 memperlihatkan bahwa jumlah produksi paprika mengalami fluktuasi. Pada tahun 2014, produksi paprika berhasil mencapai 7.028 ton. Sedang tahun 2015 mengalami penurunan menjadi 5.658 ton dan tahun 2016 menjadi 5.256 ton. Kemudian terjadi peningkatan pada tahun 2017, berhasil mencapai 7.390 ton.

Meski mengalami fluktuasi, Jawa Barat menjadi provinsi dengan produksi paprika tertinggi di Indonesia selama 2014-2017. Pada tahun 2014, Jawa Barat berhasil memproduksi 4.489 ton. Namun pada tahun 2015 dan 2016 terjadi penurunan menjadi 3.333 ton dan 3.127 ton. Peningkatan produksi kembali terjadi pada tahun 2017 yakni menjadi 5.104 ton.

Seperti yang dilansir oleh worldatlas.com ${ }^{1}$, Indonesia menempati posisi ke-4 sebagai negara penghasil cabai terbanyak di dunia dengan total

1Maureen Shisia. The World's Top Chili Pepper Producing Countries. https://www.worldatlas.com/articles/the-world-stop-chili-pepper-producing-countries.html diakses pada Jumat, 14 September 2018 pukul 10.00 WIB. produksi 1,9 juta ton di bawah Cina, Meksiko, dan Turki. Food and Agriculture Organization of the United Nations (FAO) merilis data yang menyatakan bahwa rata - rata luas panen cabai tahun 2009 - 2013 Indonesia menempati urutan pertama sebagai negara dengan luas panen cabai dan paprika hijau terbesar di ASEAN dengan rata-rata kontribusi sebesar 96,22\% dari total luas panen cabai dan paprika hijau ASEAN. Dengan demikian, Indonesia berpotensi besar untuk dapat memenuhi kebutuhan paprika di pasar ASEAN. Akan tetapi, tingginya prospek pemasaran komoditas paprika baik domestik maupun internasional ternyata belum didukung oleh upaya-upaya pengembangan produksi. Hal ini berakibat pada rendahnya tingkat produksi paprika di Indonesia.

Salah satu daerah yang potensial untuk membudidayakan tanaman tersebut di Jawa Barat adalah Desa Pasirlangu, Kecamatan Cisarua, Kabupaten Bandung Barat. Desa Pasirlangu berada pada ketinggian 900-2050 mdpl dengan suhu rata - rata $20-25^{\circ} \mathrm{C}$, sehingga desa ini cocok untuk perkebunan dan tanaman hortikultura. Mata pencaharian penduduk Desa Pasirlangu pun sebagian besar adalah petani dan buruh tani. Dalam beberapa tahun terakhir paprika mampu meningkatkan pendapatan petani dan meningkatkan kesejahteraan masyarakat. Harga jual yang relatif stabil dan tanaman ini relatif lebih cepat menghasilkan buahnya menjadi alasan paprika untuk terus dibudidayakan.

Seiring dengan perubahan kondisi alam, bertani paprika tidak semudah saat pertama bertani pada tahun 1995 lalu. Para petani mengeluhkan hama yang makin mudah menyerang tanaman mereka. Selain itu, bertani paprika membutuhkan modal yang cukup besar, para petani pun siap apabila harus beralih ke komoditas yang lain apabila modal mereka tidak cukup. 
Kurangnya perhatian pemerintah terhadap para petani Desa Pasirlangu pun membuat petani berorientasi hanya untuk memenuhi kebutuhan ekonomi mereka. Pemerintah saat ini pun fokus memberi penyuluhan kepada kelompok tani dan mengesampingkan petani individu. Hal ini menimbulkan kecemburuan pada petani individu.

Sebagai desa yang sangat potensial dalam menghasilkan paprika, Desa Pasirlangu saat ini justru dalam keadaan terancam dari sisi sumber daya manusia. Peneliti melihat generasi muda Desa Pasirlangu memiliki pemikiran untuk memperoleh pendidikan yang lebih tinggi dan tidak ingin berprofesi sebagai petani. Para petani Desa Pasirlangu pun tidak berharap banyak pada generasi muda untuk menjaga, meneruskan, dan meningkatkan potensi Desa Pasirlangu di masa depan.

Permasalahan ini ternyata sudah diprediksi oleh Nurhady Sirimorok, peneliti dari Ininnawa. Dalam sebuah diskusi di Makassar akhir Mei 2015, Ia mengatakan bahwa beberapa tahun ke depan kita akan menemukan banyak generasi muda yang meninggalkan desa, dan dari sinilah akan menimbulkan masalah baru, dengan semakin jauhnya mereka dari pertanian. ${ }^{2}$

Dengan segala kondisi yang dialami oleh Desa Pasirlangu, hal yang menarik untuk dikaji adalah pola komunikasi yang terjadi di Desa Pasirlangu baik secara individu maupun kelompok. Selain itu, peneliti mencoba memetakan kondisi yang ada di Desa Pasirlangu. Peneliti berharap dengan memetakan pola komunikasi pertanian ini akan memberikan pemetaan permasalah yang ada disana.

2Wahyu Chandra. Petani Berkurang, Masa Depan Pertanian Indonesia Terancam http://www.mongabay.co.id/2015/06/25/ petani-berkurang-masa-depan-pertanian-indonesia-terancam/ diakses pada Jumat, 14 September 2018 pukul 10.00 WIB.

\section{METODE}

Penelitian ini menggunakan jenis penelitian kualitatif dengan tradisi studi kasus.

Qualitative research is an inquiry process of understanding based on distinct methodological traditions of inquiry that explore a social or human problem. The researcher builds a complex, holistic picture, analyzes word, reports detailed views of informants, and conducts the study in a natural setting (Cresswell, 1998: 15)

Tradisi studi kasus menurut Creswell adalah suatu upaya untuk eksplorasi sebuah sistem yang terikat atau sebuah kasus. Subjek dalam penelitian ini adalah masyarakat Desa Pasirlangu. Sedang untuk objek penelitian adalah aktivitas komunikasi masyarakat Desa Pasirlangu. Pengumpulan data dalam penelitian ini didapatkan dengan menggunakan teknik wawancara mendalam dengan beberapa orang petani paprika dan tokoh masyarakat. Diantaranya adalah Saefudin (Kepala RW 3); Ermis (Petani paprika senior); Rici Solihin (Petani muda dan Duta Tani Indonesia 2016-2018); Risma \& Selviira (Remaja asli Desa Pasirlangu). Selain wawancara mendalam, peneliti juga melakukan observasi mengenai aktivitas masyarakat Pasirlangu seperti bertani paprika. Analisis data dilakukan dengan menggunakan teknik analisis data interaktif Miles dan Huberman yaitu pengorganisasian data, klasifikasi dan kategori data, serta verifikasi data.

\section{HASIL DAN PEMBAHASAN}

\section{Potret Permasalahan Pertanian Desa}

\section{Pasirlangu}

Pasirlangu, Kecamatan Cisarua, Kabupaten Bandung Barat, Indonesia, merupakan sebuah desa pertanian yang cukup terkenal di dunia pertanian Indonesia bahkan di mancanegara. 
Desa ini yang terletak $26 \mathrm{~km}$ dari Ibu Kota Jawa Barat dengan luas $10,07 \mathrm{~km}^{2}$ berpenduduk 11.534 orang. Desa dengan ketinggian 1400 meter di atas permukaan laut memiliki hasil utama berupa pertanian tanaman paprika telah dinobatkan sebagai penghasil paprika nomor satu di Indonesia. Konsumen paprika asal Desa Pasirlangu ini sangat luas, mulai dari pasar tradisional, pasar modern, hotel, restoran, hingga pengiriman keluar kota, bahkan diekspor ke beberapa negara. Pasirlangu sukses dan semakin maju semenjak keberadaan komoditas paprika sebagai tanaman utama dalam pertaniannya.

Sebelum tahun 1980-an, Pasirlangu masih seperti kebanyakan desa pertanian di Indonesia. Dengan komoditas awal berupa tanaman labu siam, membuat kehidupan masyarakat Pasirlangu serba pas-pasan dan kurang dikenal oleh masyarakat. Belum lagi beberapa warganya memang tidak menjual hasil labu siam yang ditanam, tetapi untuk konsumsi pribadi. Hingga pada 1987 paprika datang dan diperkenalkan oleh seorang warga asli Pasirlangu, Bapak Tahyan, yang merupakan alumni dari IPB (Institut Pertanian Bogor). Bapak Tahyan mengajak 11 warga dan petani lainnya untuk melakukan percobaan budidaya paprika dengan menggunakan arang sekam dan menggunakan bibit dari Belanda, yaitu PT. Zoro, bekerjasama dengan Saung Mirwan, Bogor dan hasilnya memuaskan. Semenjak itu, hingga saat ini paprika menjadi terus berkembang di Pasirlangu.

Semenjak kehadiran paprika di Pasirlangu, perekonomian masyarakat terus berkembang pesat. Hasil tani yang ditawar dengan harga tinggi dan permintaan ekspor yang cukup banyak membuat satu persatu petani di Pasirlangu mulai menggeluti tanaman paprika. Hingga kini, tercatat $37,30 \%$ masyarakat Pasirlangu merupakan petani dan $17,02 \%$ dari jumlah penduduknya bekerja sebagai buruh tani dan 1,27\% merupakan pelaku UMKM.

Sebagian besar petani paprika di Pasirlangu mengembangkan usaha paprikanya dengan cara otodidak. Percobaan demi percobaan dilakukan untuk mengembangkan pengetahuan baru mereka, baik dari cara pengelolaan tanaman hingga cara pembasmian hama. Sayangnya, ilmu-ilmu pertanian yang sudah teruji secara ilmiah jarang digunakan. Salah satu faktor tidak digunakannya ilmu pengelolaan pertanian yang sudah teruji adalah rendahnya tingkat pendidikan. Tingkat pendidikan di Desa Pasirlangu didominasi oleh lulusan SD atau sederajat sebanyak 52,66\%, sedangkan lulusan SMP atau sederajat sebanyak $10,68 \%$, SMA sebanyak 7,44\%, dan pendidikan tinggi sebanyak $0,41 \%$. Pendidikan tinggi pun didominasi oleh generasi baru yang tidak mendalami ilmu pertanian. Percobaan tanpa dasar ilmu tersebut menjadikan petani bebas bereksperimen tanpa pikir efek negatif yang dapat terjadi terhadap lingkungan. Terutama pada penggunaan pestisida.

Dalam mengatasi hama, virus dan penyakit tanaman paprika yang semakin hari semakin membandel, petani di Pasirlangu melakukan pencampuran cairan pestisida dengan campurancampuran lainnya, diantaranya dengan pestisida dengan jenis yang berbeda, sabun, bahkan campuran bensin. Campuran-campuran tersebut tidak diuji secara klinis tentang baik atau tidaknya untuk digunakan pada tanaman paprika. Selain itu, sumber serapan yang menjadi salah satu hal yang cukup penting di desa pertanian pun tidak tersedia di desa Pasirlangu.

Virus dan hama paprika yang semakin hari semakin kebal terhadap pestisida, mengakibatkan banyak kerugian yang dialami oleh petani. Mulai dari biaya penggunaan pestisida yang naik, hingga ancaman kegagalan panen yang 
semakin besar. Petani harus bekerja ekstra untuk mempertahankan pertaniannya. Belum lagi keterbatasan ilmu membuat petani paprika kewalahan menyelesaikan permasalahan pertanian yang terus bermunculan.

Selama ini, ada upaya pemerintah untuk mengedukasi petani di Pasirlangu melalui pelatihan-pelatihan pertanian yang dilakukan minimal satu tahun sekali. Sayangnya, pelatihan tersebut tidak berjalan dengan lancar dan tidak dirasakan manfaatnya secara langsung oleh petani di Pasirlangu. Beberapa kendala dan permasalahan perencanaan pelatihan membuat petani paprika Pasirlangu tidak teredukasi dengan baik diantaranya, sasaran pelatihan dari pemerintah yang lebih membidik petani-petani kelompok dan petani-petani besar, sedangkan tidak semua petani paprika di Pasirlangu bertani secara berkelompok. Ada beberapa petani yang masih menjalani pertaniannya secara kecilkecilan. Selain itu, peserta pelatihan yang hadir biasanya adalah petani yang merupakan pemilik lahan pertanian, hanya sedikit saja buruh tani yang ikut serta dalam proses pelatihan pertanian yang ada. Padahal yang terjun langsung ke lapangan adalah buruh tani, petani pemilik lahan pertanian biasanya hanya mengontrol saja.

Permasalahan lain dirasakan adalah ketakutan buruh tani untuk mempraktekkan ilmu baru yang diajarkan dari pelatihan-pelatihan yang didapatkan. Alasannya, adalah biaya produksi paprika yang cukup mahal, sehingga jika terjadi kegagalan maka akan mengalami kerugian yang besar pula. Buruh tani tidak berani mengambil keputusan berisiko karena keterbatasan pendapatan mereka yang tidak begitu besar dari hasil bekerja pada perkebunan paprika milik orang lain. Biasanya, pelatihan dan penyuluhan pemerintah akan terasa hasilnya pada beberapa bulan awal pasca pelatihan saja. Hal itu disebabkan karena adanya monitoring dari pihak pemerintah. Namun setelahnya, kembali pada kegagalan-kegagalan dan permasalahan yang sudah terjadi sebelumnya.

Pada dasarnya penyelenggaraan penyuluhan dari Balai Penelitian Tanaman Sayur Lembang (Balitsa) pada dasarnya menitik beratkan pada analisis dan pemecahan berbagai permasalahan usaha tani. Penyuluhan pertanian adalah sebuah proses pendidikan yang bertujuan untuk menumbuhkan partisipasi melalui proses belajar mengajar sistem dengan menampilkan peran sebagai motivator masyarakat petani secara optimal melalui komunikator yang kredibel. Pesan dari komunikasi yang disampaikan harus disesuaikan dengan kondisi petani Pasirlangu. Kemudian metode penyampaian pesan juga mengikuti gaya komunikasi dari para petani Pasirlangu. Balitsa Lembang harus menyadari bahwa saat ini petani Pasirlangu sangat dinamis dengan perkembangan teknologi komunikasi yang ada.

Menurut Dr. Ir. Cecep Hidayat, M.P., Dosen Prodi Agronomi UIN SGD Bandung dan Alumnus Fakultas Pertanian Universitas Padjadjaran, perlunya kebaruan dalam sistem penyuluhan. Contohnya dengan kunjungan yang terjadwal dan siap sedia dari penyuluh pada petani individual dan petani kelompok kecil, pemanfaatan sarana handphone dan media sosial secara maksimal.

"Pola penyuluhan klasikal seiring berjalannya waktu tampaknya semakin sulit dilaksanakan. Sebagai gantinya perlu dipikirkan kunjungan penyuluh yang bersifat individual atau kelompok kecil. Dibuat sistem komunikasi antara petani dan penyuluh menggunakan sarana HP. Petani menghubungi Penyuluh untuk memperoleh masukan teknis tentang persoalan budidaya tanaman. Penyuluh dalam posisi on call, siap untuk menerima panggilan dari Petani. Penyuluh dapat juga membuat rencana kunjungan ke kelompok kecil petani 
untuk membahas atau memberikan informasi teknis yang dibutuhkan Petani. Juga dapat digunakan media medsos, memanfaatkan HP yang dimiliki Petani."3

Permasalahan lainnya datang dari pihak petani sendiri. Rendahnya tingkat pendidikan mengakibatkan petani yang kesulitan memahami pengetahuan dan teknologi baru yang diperkenalkan. Bahkan pengetahuan baru yang sudah teruji ilmiah pun kurang digubris. Mayoritas petani lebih mempercayai ilmu leluhur yang sudah diterapkan secara turun menurun. Selain itu, petani juga lebih mementingkan pendapatan mereka dari segi keuangan. Waktu yang digunakan untuk mengikuti pelatihan pengelolaan pertanian dirasa cukup memakan waktu, sehingga pendapatan yang semestinya mereka dapatkan dari hasil kerja mereka, hilang karena harus menghabiskan waktu mengikuti pelatihan. oleh sebab itu, pelatihan-pelatihan yang bersifat tanpa feedback bayaran untuk petani jarang diminati.

Hasil pertanian paprika dapat digolongkan menjadi 4 grade (tingkatan). Grade tersebut dinilai dari kualitas dan bentuk paprika setelah dipanen. Adapun grade kualitas paprika tersebut adalah : A, B, C dan CX. Setiap grade memiliki harga jual yang berbeda. pada grade $\mathrm{C}$ dan $\mathrm{CX}$, nilai jualnya sangat rendah sehingga menjadi salah satu faktor kerugian yang dialami oleh petani. Dalam hal ini, dibutuhkan ide-ide alternatif dari petani untuk mengelola paprika dengan grade rendah agar dapat dijual dengan harga yang tidak merugikan.

\section{Potret Permasalahan Infrastruktur Desa Pasirlangu}

Infrastruktur merupakan hal kecil namun sangat penting dalam roda kehidupan desa. Dana desa yang dialokasikan oleh pemerintah pusat sebaiknya dibelanjakan untuk infrastruktur dan pengembangan pertanian paprika. Infrastruktur yang memadai, tepat guna, dan dibangun dengan baik tanpa mengeksploitasi wilayah pedesaan secara berlebihan akan memudahkan masyarakat untuk beraktivitas. Infrastruktur yang tepat guna dan dibangun dengan baik.

Kondisi yang terjadi di Desa Pasirlangu adalah kondisi jalan baik dari arah Cisarua, Lembang maupun dari Padalarang cukup memprihatinkan. Banyak jalan yang sudah berlubang besar, tidak rata, dan licin. Ini sangat membahayakan saat berkendara dengan kendaraan bermotor.

Sarana transportasi untuk menuju Desa Pasirlangu pun sudah tidak aktif lagi. Kabarnya dahulu ada angkutan yang beroperasi namun sudah tidak lagi beberapa tahun ini. Akibatnya setiap keluarga di Desa Pasirlangu setidaknya harus memiliki satu kendaraan bermotor roda dua untuk memudahkan mobilisasi.

Selain jalanan desa yang kurang baik, sarana pendidikan di Pasirlangu pun tidak semuanya ada. pendidikan negeri dari tingkat dasar, menengah dan menengah atas tidak lengkap di Pasirlangu. Di Pasirlangu, hanya ada sekolah dasar negeri dan sekolah menengah pertama dan atas yang berstatus swasta. Sehingga, banyak pemuda yang memilih keluar desa untuk melanjutkan pendidikannya, dan bahkan ada yang memilih untuk tidak melanjutkan pendidikan dan menjadi buruh tani. 


\section{Potret Permasalahan Sosial Desa Pasirlangu}

Secara sosial, penduduk desa dimaknai sebagai sekumpulan orang yang relatif saling mengenal secara individu dan memiliki kesatuan kebudayaan yang membentuk suatu komunitas. Kehidupan sosial di Desa Pasirlangu menarik untuk diketahui karena mengalami beberapa permasalahan sosial yang mempengaruhi sisi kehidupan yang lain. Permasalahan tersebut diantaranya adalah sikap apatis warga, menurunnya minat generasi muda untuk menjadi petani, kesenjangan antara petani besar dan buruh tani, serta tindak kriminalitas.

Masyarakat desa terkenal dengan gotong royong, senasib sepenanggungan, saling peduli satu sama lain. Akan tetapi sedikit berbeda dengan penduduk Desa Pasirlangu. Beberapa penduduk Desa Pasirlangu mengakui bahwa kehidupan mereka mulai apatis. Hal ini disebabkan karena masing - masing penduduk fokus untuk mencari penghasilan. Tidak aktifnya organisasi kemasyarakatan seperti Karang Taruna dan PKK (Pendidikan Kesejahteraan Keluarga) berdampak pada pola komunikasi masyarakat yang kurang jelas.

Di samping itu, pandangan generasi muda terhadap profesi petani pun berubah. Banyak generasi muda Desa Pasirlangu yang memprioritaskan pendidikan. Beberapa dari mereka bahkan sejak menginjak Sekolah Menengah Pertama sudah memilih tempat menimba ilmu terbaik di Cimahi dan Bandung. Hal ini dibenarkan oleh salah seorang orang tua remaja Pasirlangu, Ibu Sri Nur Handayani,

"Para remaja Desa Pasirlangu sudah berusaha mencari pendidikan terbaik dengan keluar dari zona nyaman. Mereka bersekolah ke Cimahi sampai Bandung."

4 Wawancara langsung dengan salah satu ibu rumah tangga Pasirlangu, Sri Handayani pada 16 September 2018.
Para generasi muda Desa Pasirlangu yang memilih menimba ilmu jauh dari desa memiliki kecenderungan untuk tidak kembali ke desa. Mereka lebih memilih untuk berkarir di luar desa. Baik sebagai pengajar, tentara, dan profesi lain selain bertani. Profesi petani seakan menjadi pilihan bagi mereka yang hanya lulus SMP atau SMA dan tidak melanjutkan pendidikan ke jenjang yang lebih tinggi.

Selanjutnya, kesenjangan sosial diantara petani besar dan buruh tani di Desa Pasirlangu. Petani besar mendapatkan untung cukup besar karena mereka tidak hanya bertani namun mengelola toko pertanian. Sedangkan buruh tani hanya bekerja untuk kebun orang lain dan belum mampu memiliki lahan sendiri. Buruh tani hanya mendapatkan kurang dari Rp 100.000/ hari. Sehingga, fenomena ini menimbulkan kesenjangan sosial yang berdampak pada meningkatnya angka kriminalitas.

Sebagian masyarakat menganggap hidup di desa dapat dengan tenang tanpa adanya tindak kriminalitas. Ada desa yang bahkan kunci motor tertinggal di motor pun tidak akan hilang. Sebagian percaya bahwa desa aman karena saling peduli dan percaya. Hidup di lingkungan pedesaan, tidak menutup kemungkinan tindak kriminalitas terjadi. Di Desa Pasirlangu, beberapa kali terjadi tindak kriminalitas. Pelaku menargetkan pada hasil tani paprika yang belum dipetik di kebun. Baru - baru ini, tindak kriminalitas merambah pada pencurian sepatu olahraga yang sepasangnya berkisar ratusan ribu rupiah.

\section{Pola Komunikasi Petani Desa Pasirlangu}

Dari hasil lapangan yang diperoleh peneliti, pola komunikasi para petani di Desa Pasirlangu, Kampung Pasirlangu, Bandung dapat dibagi menjadi dua, yaitu pola komunikasi petani kelompok dalam kelompok tani dan pola 
komunikasi petani individu.

Petani individu didefinisikan sebagai petani yang menggarap hasil taninya secara sendiri tanpa bergabung dengan para petani lain. Petani individu akan melakukan seluruh proses pertanian sendirian, kemungkinan keterlibatan orang lain dalam pertaniannya hanya sebagai buruh saja (jika ada). Pada petani individu tidak memiliki ketua petani. Sedangkan petani kelompok adalah petani yang tergabung dengan beberapa petani lainnya yang sama-sama bertani tanaman yang sama,yaitu paprika. Para petani ini bergabung menjadi sebuah kelompok yang dikenal dengan istilah kelompok tani. Pada kelompok tani biasanya memiliki satu ketua dan beberapa anggota yang bersama-sama untuk membangun pertanian mereka.

Pada petani individu proses pengembangan ilmu bertani dalam bercocok tanam hingga pencegahan dan pembasmian hama seringkali didapatkan dari proses pengalaman sendiri. Petani individu akan melakukan eksperimen sendiri terhadap pembasmian hama sehingga menemukan kiat-kiat baru dalam pengelolaan pertanian pada kebun paprika milik mereka. Pada proses komunikasi yang dilakukan biasanya bersifat antarpribadi, yaitu pencarian informasi pertanian melalui berbagi ilmu dan cerita dengan petani individu lainnya. Informasi yang didapatkan jarang sekali bersifat ilmiah atau bersumber dari ahli pertanian, tetapi lebih pada hasil pengalaman.

Pada petani kelompok, proses pengembangan ilmu bertani lebih terstruktur. Ketua kelompok tani memiliki tanggung jawab terhadap kelompok tani yang bergabung bersamanya. Sebuah kelompok tani akan bersama-sama mengembangkan pertanian mereka dengan ilmuilmu yang dibagi tidak secara individual, tetapi menyeluruh pada semua anggota kelompok tani.
Biasanya, ketua kelompok tani adalah seseorang yang memiliki kemampuan lebih baik dari segi keilmuan dalam pertanian maupun proses pemasaran hasil pertanian mereka. Hal ini dikarenakan orang tersebut dianggap memiliki kemampuan kognitif dan finansial yang lebih baik dibandingkan anggotanya.

Selain itu, petani kelompok juga lebih sering mendapatkan penyuluhan dan pelatihan dari pihak pemerintah, karena biasanya kelompok tani merupakan kelompok tani yang terdata di pemerintahan setempat.

Antara pola komunikasi petani individu dan petani kelompok tentu saja terlihat begitu berbeda. Petani individu akan berjuang sendiri untuk mencari informasi untuk pengembangan pertanian paprika miliknya. informasi yang didapatkan juga cukup terbatas, karena pada petani individu hampir tidak pernah turut serta dalam penyuluhan dari pemerintah. Berbeda dengan kelompok yang memiliki satu opinion leader yang membantu mengarahkan pengelolaan pertanian paprika anggota kelompok tani agar berhasil bersama.

Permasalahan komunikasi yang dihadapi oleh petani paprika di Pasirlangu adalah ketertutupan informasi. Para petani yang mulai menjadikan finansial sebagai target utama menjadi mulai bersaing secara tidak sehat. Persaingan ketat antar petani pun mulai terasa begitu jelas, sehingga pemberian informasi mengenai ilmu pertanian paprika sudah cukup jarang dilakukan antar petani, khususnya antar petani individu yang satu dengan yang lainnya, dan antar satu kelompok tani dengan kelompok tani yang lainnya.

Dengan kata lain, pola komunikasi antara petani individu dan kelompok di Desa Pasirlangu berbeda. Pola komunikasi pada petani individu dapat dikategorikan sebagai 
primer dan sekunder. Hal ini dikarenakan petani berkomunikasi secara langsung antar petani. Selain itu, mereka menggunakan aplikasi pesan yang ada di handphone untuk bertukar informasi. Sedangkan pola komunikasi yang terjadi pada petani kelompok juga primer, sekunder, dan sirkular. Karena petani kelompok berkomunikasi secara langsung dan menggunakan media seperti handphone. Selain itu, komunikasi petani kelompok terjadi feedback sehingga berbentuk lingkaran yang saling berhubungan atau disebut dengan pola komunikasi sirkular.

\section{KESIMPULAN}

Berdasarkan hasil pembahasan di atas dapat disimpulkan sebagai berikut:

1. Desa Pasirlangu adalah desa penghasil komoditas paprika terbesar di Indonesia yang menghadapi persoalan dari sisi pertanian, pendidikan, sosial, dan infrastruktur.

2. Ada dua pola komunikasi petani Desa Pasirlangu yaitu pola komunikasi petani individu dan kelompok.

3. Pola komunikasi pada petani individu dapat dikategorikan sebagai primer dan sekunder. Hal ini dikarenakan petani berkomunikasi secara langsung antar petani. Selain itu, mereka menggunakan aplikasi pesan yang ada di handphone untuk bertukar informasi.

4. Pola komunikasi yang terjadi pada petani kelompok adalah primer, sekunder, dan sirkular. Petani kelompok berkomunikasi secara langsung dan menggunakan media seperti handphone. Selain itu, komunikasi petani kelompok terjadi feedback sehingga berbentuk lingkaran yang saling berhubungan atau disebut dengan pola komunikasi sirkular.

5. Dibutuhkan sejumlah pelatihan yang menarik dan berkelanjutan sesuai dengan karakteristik warga Pasirlangu untuk meningkatkan minat mendalami ilmu pertanian secara ilmiah dan mempraktekkannya di lapangan. Seperti penciptaan produk kerugian pada paprika yang berkualitas olahan paprika untuk menyeimbangi rendah. Kemudian pelatihan mengenai pemasaran agar petani yang terbiasa dengan tengkulak dapat lebih mengerti cara memasarkan produknya dengan baik dan mampu memasarkan produk olahan paprika ke pasaran. Khusus bagi kelompok tani, diperlukan suatu bimbingan yang spesifik dan berkelanjutan dari ketua dalam kelompok untuk kedinamisan kelompoknya.

\section{DAFTAR PUSTAKA}

Adams, M.E. 1982. Agricultural Extension in Developing Countries. Singapore: Longman Singapore Publisher.

Ban, A.W. van den \& H.S. Hawkins. 1999. Penyuluhan Pertanian. Terjemahan oleh Agnes Dwina Herdiasti. Yogyakarta: Kanisius.

Creswell, Jhon W. 2010. Qualitative Inquiry and Research Design Choosing Among Five Tradition. United States of America: Sage Publikation.

Nanang Nasikhin. 2015. "Pola Komunikasi dalam Meningkatkan Budaya Gotong Royong Kelompok Tani Dusun Sukorejo Kelurahan Lempake". EJournal Ilmu Komunikasi Fisip Unmul, 3(1) 2015, 87-100.

Soekartawi. 1988. Prinsip Dasar Komunikasi Pertanian. Jakarta: UI Press.

Sukino. 2013. Membangun Pertanian dengan 
Pemberdayaan Masyarakat Tani.

Yogyakarta: Pustaka Baru Press.

Suharto, Edi. 2005. Membangun Masyarakat Memberdayakan Masyarakat. Bandung: Refika Aditama 